\title{
Some remarks on the taxonomy of Antarctic Leuconidae (Cumacea: Crustacea) with a description of a new species Leucon intermedius n. sp.
}

\author{
U. Mühlenhardt-Siegel \\ Zoologisches Institut und Museum, Universität Hamburg; Martin-Luther-King-Platz 3, \\ D-20146 Hamburg, Germany* \\ and \\ Abt. Morphologie der Tiere, Fakultät für Biologie, Universität Bielefeld, \\ D-33615 Bielefeld, Germany
}

\begin{abstract}
The newly described species Leucon intermedius $n$. sp. differs from other known Leucon species by an inconspicuous antennal notch and the presence of only a few teeth at the dorsomedian crest. The species most similar to Leucon intermedius are L. septemdentatus and $L$. inexcavatus from the Antarctic/Subantarctic Ocean. A Table is given to allow direct comparison of the characteristics of all Leucon species known from the Antarctic/Subantarctic Ocean. Forty-one specimens of Leucon intermedius n. sp. were collected at depths ranging from 109 to $791 \mathrm{~m}$ in the vicinity of the Amery Depression (Indian Sector) and near King George Island (South Shetland Islands). Problems in distinguishing the Antarctic/Subantarctic species of the genus Eudorella are discussed. The shape of the antennal notch is suggested as a better characteristic to distinguish the Eudorella species than the proportions of the articles of extremities. On the basis of this criterion, samples at the Zoological Museum, Hamburg are made up of two species of Eudorella: gracilior and cf. fallax.
\end{abstract}

\section{INTRODUCTION}

14 species of the genus Leucon from Antarctic/Subantarctic waters have been described in scientific literature. Watling (1991) introduced subgenera for all Leucon species which were known to him. One essential characteristic for the determination of the subgenera is the length of the flagellum of antenna 1 compared to the basal segment of antenna 1. However, one species was missing in his list and others have only recently been described. For one of these species the description is incomplete, or no information is available about the described criterion; thus, a reference to the subgenus level is not possible. The subgenera and the Antarctic/Subantarctic species are: subgen. Crymoleucon: Leucon antarcticus Zimmer 1907, L. breidensis Gamo 1987, L. inexcavatus Ledoyer 1977, L. intermedius n. sp., L. kerguelensis Zimmer 1908, L. sagitta Zimmer 1907, L. septemdentatus Zimmer 1902, L. vanhöffeni Zimmer 1907; subgen. Leucon: Leucon assimilis Sars 1887, L. adelae Petrescu 1991; subgen. Macrauloleucon: Leucon

\footnotetext{
- Address for all correspondence 
parasiphonatus Mühlenhardt-Siegel 1994, L. weddelli Ledoyer 1993; subgen. Alytoleucon: Leucon polarsterni Ledoyer 1993; subgenus unidentified: Leucon meredithi Petrescu 1991.

In order to make the differential diagnosis of the Antarctic/Subantarctic species easier, a Table has been set up containing all the important characteristics. This Table can easily be extended when further new species become known. This is the major advantage of the Table in comparison to a determination key which has to be changed every time a new species is described.

Some remarks on the taxonomy of the genus Eudorella in Antarctic/Subantarctic waters are given. The classic character for the determination of Eudorella species is the shape of the anterolateral margin of the carapace, especially the antennal notch (Stebbing, 1913; Lomakina, 1968; Barnard \& Given, 1960; Jones, 1971). Watling (1991) ignores this character and prefers the proportions of the articles of the uropodal rami and the proportion (length to width) of the 6th article of pereiopod 1. The practicability of using these characteristics is discussed.

\section{MATERIAL AND METHODS}

The Eudorella species collected during German Antarctic expeditions aboard RV "Polarstern" and FRV "Walther Herwig" in the Scotia Arc region have been deposited at the Zoological Museum, Hamburg, Germany. The expeditions took place in austral summer (November/December, February to April 1984/85, October to December 1987) and the austral winter of May/June 1986. For station lists see Hempel (1985), Anonymous (1986), Fütterer (1988) and Anonymous (1990).

Sampling gear was a van Veen grab $\left(0.1 \mathrm{~m}^{2}\right.$ size $)$. All grab samples were sieved at once using a $0.5 \mathrm{~mm}$ screen mesh, and the benthos was fixed in $4 \%$ borax-buffered formalin-seawater solution. All sorting was carried out at a later date using a stereo microscope. The material was transferred to $70 \%$ ethanol for preservation.

459 specimens of Eudorella gracilior and 727 specimens of Eudorella cf. fallax were identified. The material from the Amery Depression in the Indian Ocean Sector was collected by M. O'Loughlin. This sampling was also carried out with a van Veen grab and an epibenthic sledge during the Australian Antarctic Expedition in January and February 1993. 47 specimens of Eudorella gracilior were present in the material collected during the above Australian Antarctic Expedition.

Types and paratypes of the newly described species have been deposited at the Museum of Victoria, Melbourne, Victoria 3000, Australia.

$\mathrm{H}$ o $\mathrm{l}$ o $\mathrm{t}$ y $\mathrm{p}$ e: $\mathrm{J} 38352$, adult female, $3.66 \mathrm{~mm}$ length.

T y p e 1 o c a 1 i t y: $68^{\circ} 36.87^{\prime} \mathrm{S} 74^{\circ} 31.11^{\prime}$ E, Amery Depression, $694 \mathrm{~m}$, diatomaceous clay,

D a t e: 22nd January 1993

$\mathrm{P}$ a $\mathrm{r}$ a $\mathrm{t}$ y $\mathrm{p}$ e s: J 38360 , subadult male, $3.66 \mathrm{~mm}$ length.

L o c a 1 i t y: $68^{\circ} 26.47^{\prime} \mathrm{S} 74^{\circ} 22.23^{\prime} \mathrm{E}$, Amery Depression, $689 \mathrm{~m}$,

D a t e: 17 th February 1993

J 38352, adult female, $3.71 \mathrm{~mm}$ length. 1 juvenile female, 5 subadult females, 1 juvenile male, 3 subadult males. 
Locality and date: same as holotype.

Additional material examin ed: $J 38359,1$ adult female carrying 7 eggs, used for SEM, 3 adult females, 2 subadult males. $68^{\circ} 56.69^{\prime} \mathrm{S} 73^{\circ} 36.78^{\prime} \mathrm{E}$ to $68^{\circ} 56.63^{\prime}$. S $73^{\circ} 37.53^{\prime} \mathrm{E}, 786$ to $791 \mathrm{~m}$, Amery Depression (17th February 1993).

$\mathrm{J} 38350,1$ adult female carrying eggs, 1 adult female, 1 juvenile female. $68^{\circ} 42.20^{\prime} \mathrm{S}$ $77^{\circ} 30.22^{\prime} \mathrm{E}$, SW Davis Base, $710 \mathrm{~m}$, silty fine sand (17th January 1993).

$\mathrm{J} 38351,2$ adult females carrying eggs, 5 subadult females. $68^{\circ} 59.20^{\prime} \mathrm{S} 74^{\circ} 59.56^{\prime} \mathrm{E}$, Amery Depression, $746 \mathrm{~m}$, diatomaceous ooze (22nd January 1993).

$\mathrm{J} 38353,5$ subadult females, 2 juvenile females, $68^{\circ} 27.06^{\prime} \mathrm{S} 74^{\circ} 12.38^{\prime} \mathrm{E}$, Amery Depression, $687 \mathrm{~m}$, sandy diatomaceous ooze (22nd January 1993).

$\mathrm{J} 38354,1$ adult female, 1 subadult female, $68^{\circ} 56.63^{\prime} \mathrm{S} 73^{\circ} 34.16^{\prime} \mathrm{E}$, southern part of Amery Depression, $783 \mathrm{~m}$, coarse, sandy clay (23rd January 1993).

$\mathrm{J} 38355,1$ adult female carrying eggs, 1 subadult female, $68^{\circ} 6.15^{\prime} \mathrm{S} 72^{\circ} 14.90^{\prime} \mathrm{E}$, Amery Depression, $788 \mathrm{~m}$, diatomaceous clay (28th January 1993).

$\mathrm{J} 38356,2$ adult females, $66^{\circ} 53.69^{\prime} \mathrm{S} 63^{\circ} 06.34^{\prime} \mathrm{E}$ to $66^{\circ} 53.67^{\prime} \mathrm{S} 63^{\circ} 05.51^{\prime}$ E, western MacRobertson Shelf, 367 to $439 \mathrm{~m}$ (11th February 1993).

J 38357, 1 adult female, $67^{\circ} 16.12^{\prime} \mathrm{S} 65^{\circ} 25.23^{\prime} \mathrm{E}$ to $67^{\circ} 16.47^{\prime} \mathrm{S} 65^{\circ} 25.75^{\prime} \mathrm{E}$, MacRobertson Shelf, edge of Nielsen Basin, 109 to $121 \mathrm{~m}$ (12th February 1993).

$\mathrm{J} 38359,1$ subadult male, $68^{\circ} 04.36^{\prime} \mathrm{S} 72^{\circ} 17.81^{\prime} \mathrm{E}$ to $68^{\circ} 04.44^{\prime} \mathrm{S} 72^{\circ} 18.11^{\prime} \mathrm{E}$, Amery Depression, $765 \mathrm{~m}$ (17th February 1993).

1 juvenile male, $62^{\circ} 04.94^{\prime} \mathrm{S} 57^{\circ} 38.97^{\prime} \mathrm{W}$, King George Island (South Shetland Islands), soft clay, $280 \mathrm{~m}$ (12th November 1987).

\section{Leucon intermedius n.sp.}

D i a g $n$ o s i s: Carapace: surface with scales. Pseudorostrum: long, turned slightly upwards, even in males rather long. Dorsomedian line: serrated with very few (4 to 7) teeth in the anterior third of the carapace, the last one or two teeth after a gap in the line. Antennal notch: shallow, very small, unpronounced. Anterolateral margin: serrated, 3 to 4 teeth dorsal of the antennal notch.

$\mathrm{E} t \mathrm{y} \mathrm{m} \circ \mathrm{l} \circ \mathrm{g} \mathrm{y}$ : the species is called $L$. intermedius because its characters are between those of $L$. septemdentatus and $L$. inexcavatus.

$\mathrm{D}$ e $\mathrm{s} \mathrm{c} \mathrm{r}$ i $\mathrm{t}$ i o $\mathrm{n}$ : The description is based on the holotype, an adult female, carrying 7 eggs in the brood pouch (Fig. 1).

Leng th: $3.4 \mathrm{~mm}$

Ey e s: none

In tegument: scaly structure on carapace, abdomen and extremities (Plate 4, Figs 1, 3).

C a r a p a c e: shorter than free thoracic segments, length: $0.75 \mathrm{~mm}$, width: $0.54 \mathrm{~mm}$, height: $0.51 \mathrm{~mm}$, no more than 6 teeth on dorsomedian line, fine setae irregularly dispersed on carapace.

Pseudorostrum: long $(0.21 \mathrm{~mm})$, with 10 fine setae on each lobus arising from the anterior margin of the pseudorostrum.

Siphonal tube (branchial tube): short, free part as long as pseudorostrum.

Antennal notch: unpronounced with 3 teeth dorsal of the antennal notch. The variability of shape of the antennal notch of 13 specimens is illustrated in Plate 2. 
Anteroventral margin of carapace: with few (4) denticles.

$5 \mathrm{free}$ thoracic seg ments $(0.84 \mathrm{~mm})$ : first segment very narrow, cephalon and thorax $(1.62 \mathrm{~mm})$ a little shorter than abdomen $(1.77 \mathrm{~mm})$.

A b d o m e n: slightly shorter than thorax, $5^{\text {th }}$ abdominal segment longer than the other, all segments covered with a few fine setae.

Tels o n: not free $(0.27 \mathrm{~mm})$, covered with some fine setae. The description of the extremities is based on the paratype ( $\mathrm{J} 38352)$ female $(3.71 \mathrm{~mm})$.

First a n te n n a (antennula) (Plate 1, Fig. a): accessory flagellum at least as long as first segment of main flagellum.

Second antenna (antenna): very small in female.

Mandible, Maxillae 1 and 2, Maxilliped 1 and 2: same as for genus in general.

Maxilli pe d 3 (Plate 1, Fig. b): basis slender, with 3 long plumose setae, exopod present with long setae.

Pereiopod 1 (Plate 1, Fig. c): longest of the extremities, basis slender, longest article; $4^{\text {th }}$ as long as $5^{\text {th }}$ article, $6^{\text {th }}$ article somewhat shorter. Exopod with long setae (not illustrated).

Pereiopod 2 (Plate 1, Fig. d): $6^{\text {th }}$ article longer than $5^{\text {th }}$. Exopod with long setae (not shown in Figure).

P e r e i o p od 3 (Plate 1, Fig. e): basis longest article, article 2 to 4 nearly equal in length, article 6 very short. Exopod with long setae (not shown in Figure).

Pereiopod 4 (Plate 1, Fig. f): $6^{\text {th }}$ article very small. No exopod, as is normal for family.

Pere i o p o d 5: not illustrated, same as in male. No exopod, as is normal for family.

U ropods: Peduncle nearly as long as exopod, with 5 spines at the inner margin, exopod longer than endopod, each ramus with 2 articles. First article of endopod with 5 spines at the inner margin, second article of endopod with 4 spines and 1 terminal one (Plate 1, Fig. g).

Differences between males and females: The paratype - a subadult male (Fig. 2) - is of the same size as the holotype. The sexual differences typical for this family - the development of antenna 2, 4 pairs of exopods at pereiopods and 2 pairs of pleopods were clearly discernible. Additional differences were observed between males and females. The carapace of male is slightly longer than the free thoracic segments. Extremities (Plate 3) are longer and stouter in the male than in the female and there are more spines at the inner margin of the uropods peduncle and endopods in the former.

\section{REMARKS}

The species bearing the closest resemblance to Leucon intermedius n.sp. is Leucon septemdentatus Zimmer 1902. Due to the paucity of teeth in the dorsomedian crest, the new species differs from $L$. septemdentatus in having very few spines at the inner margin of the uropods' peduncle and endopod. Furthermore, these spines are not plumose in males as they are in $L$. septemdentatus. The antennal notch is unpronounced, as in Leucon inexcavatus Ledoyer 1977, but in this species the dorsomedian line is serrated due to a double line with many more teeth than in $L$. intermedius n.sp. 
14 species of the genus Leucon from Antarctic and Subantarctic waters have been described up to now. Table 1 summarizes the characteristics to facilitate a comparison between these species.

\section{Genus Eudorella}

The other Antarctic/Subantarctic genus of the family Leuconidae is Eudorella with 5 described species: E. fallax Zimmer 1909, E. gracilior Zimmer 1907, E. similis Calman 1907, E. sordida Zimmer 1907 and E. splendida Zimmer 1902. Different opinions have been expressed in the literature concerning the validity of the Antarctic and Subantarctic species of the genus. Stebbing (1913) thought $E$. similis to be synonymous with E. splendida, an opinion shared by Lomakina (1968) and Ledoyer (1977). Furthermore, Stebbing related E. fallax closely to E. sordida. However, Lomakina (1968) supposed E. fallax and E. sordida to be different forms of E. splendida.

Jones (1971) established a key to the Antarctic and Subantarctic cumaceans based on Lomakina (1968) with some alterations, and distinguished E. gracilior, E. splendida and E. aff. truncatula. Barnard \& Given (1960) distinguished in their artificial key the species of the genus Eudorella and listed E. splendida, E. sordida, E. gracilior and E. fallax. The main characteristic according to this key is the shape of the anterior carapace sinus: which in E. splendida is "sinuate, with 2 evanescent serrations", in E. sordida "sinuate", in E. fallax it is "flat bottomed" and in E. gracilior it is "flat bottomed and bounded above by serrations". Watling (1991) thought E. gracilior and E. sordida to be closely related, as also E. splendida and E. similis. In his opinion, E. fallax appears to be a valid species. Watling's main characteristics to distinguish the species are as follows: the uropods' exopod is much shorter than the endopod basal article, as in E. gracilior (including E. sordida) and E. fallax. The second alternative is that the uropods' exopod is about as long as or longer than the endopod basal article (E. splendida, including $E$. similis). To separate $E$. gracilior and $E$. fallax he recommends the pereiopod 1's article 6 as a possible character. In $E$. gracilior it should be "5-6 times as long as wide, the antennule both flagella with naked margins" while in $E$. fallax article 6 is only "2-3 times as long as wide, antennule accessory flagellum with plumose setae distally on margin".

The anteroventral margin including the antennal notch as given in Barnard \& Given (1960) appears to be a very useful character when comparing the figures of Zimmer 1909, Calman 1907 and the holotype of E. splendida (Fig. 3). Taking this into consideration, E. gracilior cannot be closely related to E. sordida as suggested by Watling (1991), and E. fallax cannot be related to E. splendida as suggested by Lomakina (1968).

Based on the shape of the anterolateral margin as a main character, one can only conclude that there are two Eudorella-species in the material of the collection of the museum in Hamburg: E. gracilior and E. cf. fallax. The shape of the anterolateral margin and the antennal notch changes slightly during growth, but the main feature - the flat bottom - remains in all size groups. The denticles dorsal of the antennal notch in $E$. gracilior are formed in males at a length of about $3 \mathrm{~mm}$. The variability of the antennal notch shape of $E$. gracilior based on the material of the Victoria Museum (J 38369) and specimens from the Antarctic Peninsula area $\left(63^{\circ} 23.27^{\prime} \mathrm{S} 57^{\circ} 00.22^{\prime} \mathrm{W}\right.$ ) is shown for females (Plate. 5) and males (Plate 6).

For comparison the antennal notch shape of E. cf. fallax is shown in Plate 7. The anterior carapace sinus for this species is flat bottomed also, but the ventral carapace 


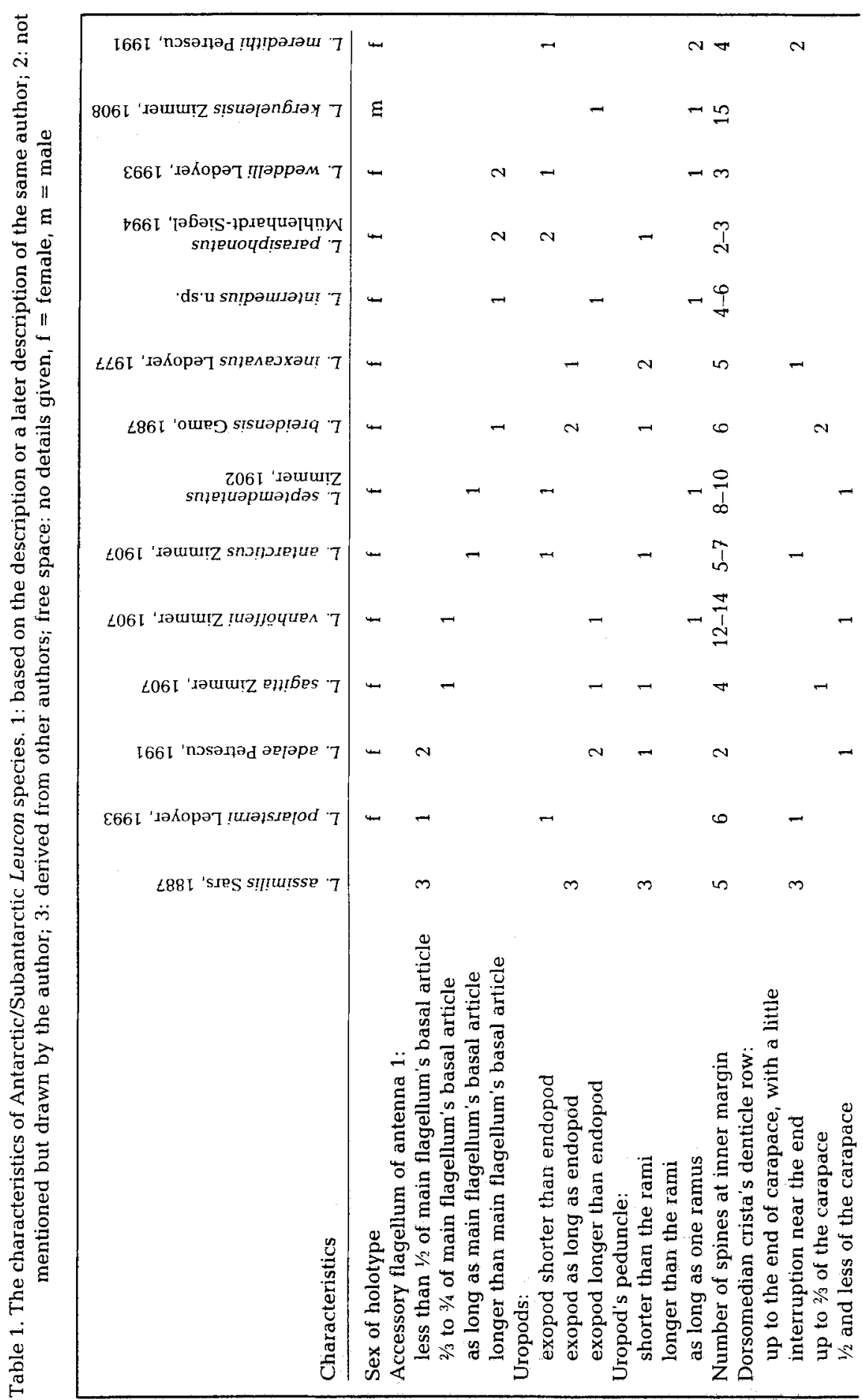




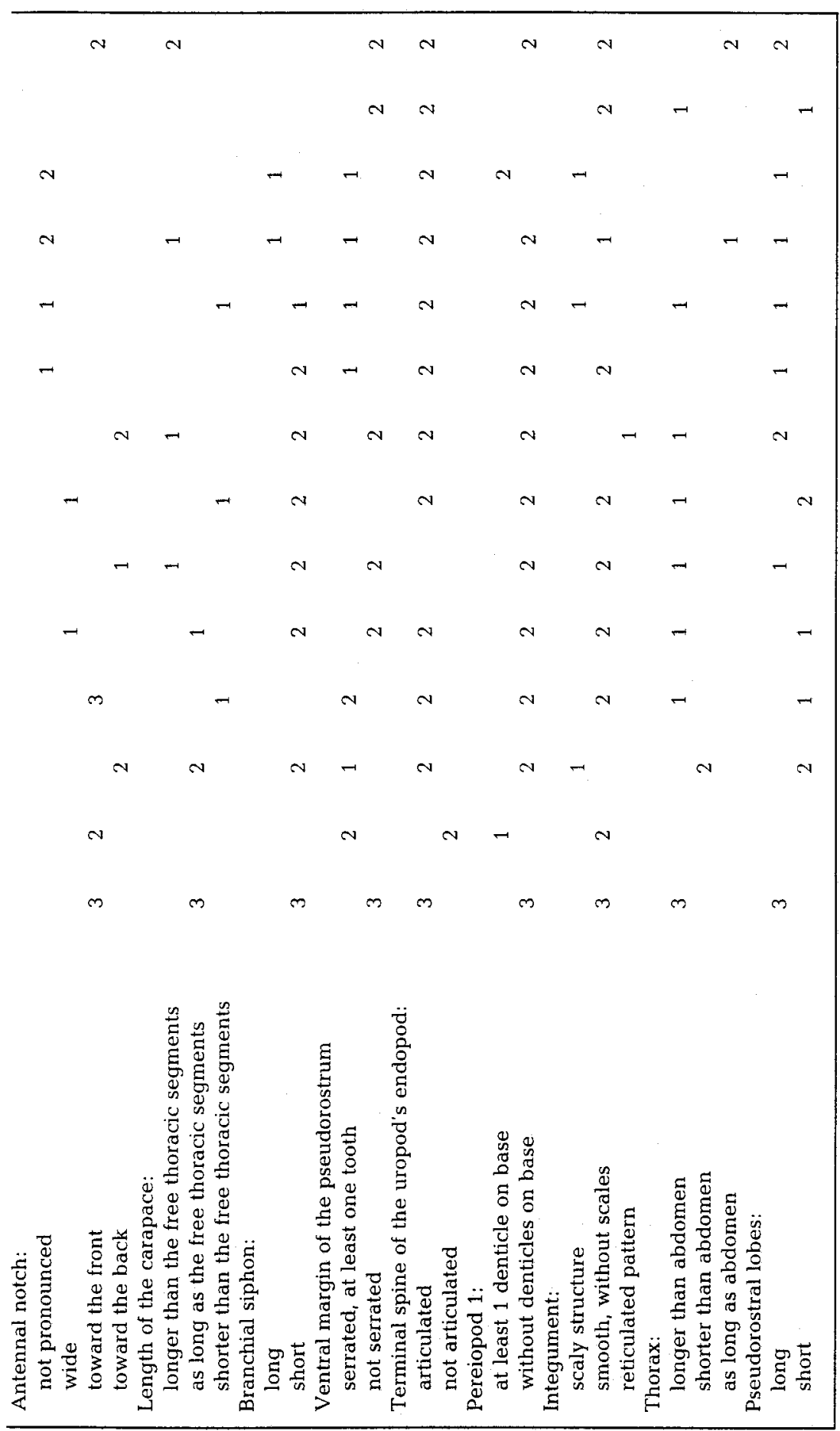


margin's teeth are very small and closely placed. Even the adults do not have teeth dorsal of the antennal notch.

Inspection of Plate 8 allows a comparison of the extremities. The uropods' peduncle shows a large number of spines: 12 in females, 14 in males, at the inner margin in $E$. gracilior, but only 4 (in males and females) in $E$. cf. fallax. The uropod endopod's inner margin of $E$. gracilior also carries many spines but has only a few in $E$. cf. fallax. According to Watling (1991), the uropod exopod is longer than the endopod's basal article in $E$. fallax. In the present material this was found not to be the case. Another character of $E$. fallax according to Watling (1991) is the length of the $6^{\text {th }}$ article of pereiopod 1, which should be 5-6 times longer than wide - in the present material this could not be found.

Unfortunately, the whereabouts of the type-material of $E$. fallax is not known (Bacescu, 1988), so a direct comparison with the types is impossible.

From the above discussion, however, it is concluded that the following species are found in the Antarctic/Subantarctic waters:

E. gracilior, E. fallax, E. sordida and E. splendida. While the artificial key to the genus Eudorella introduced by Barnard \& Given (1960) using the shape of the antennal notch as a main characteristic is very useful, the key by Watling (1991) using the length of article 6 of the pereiopod 1 and the uropod's rami is not appropriate, because the proportions of the extremities are variable during growth.

Acknowledgements. I am very grateful to my colleagues in Hamburg: Dr. D. Bürkel revised the English manuscript; Mr. H.-D. Totzke gave technical assistance. Thanks are also due to Prof. Dr. G. Hartmann (Goslar) and Prof. Dr. J. W. Wägele (Bielefeld); the study was granted by the DFG (Project Ha 138/41-1). The collection of the material from Prydz Bay was made possible by a grant to Dr. C. C. Lu and Dr. A. Constable from the Australian Antarctic Science Advisory Committee (Project No. 649). The material from Prydz Bay for the study was made available by Dr. C. C. Lu, Department of Invertebrate Zoology, Museum of Victoria.

\section{LITERATURE CITED}

Anonymous, 1986. Antarctic expeditions of the Federal Republic of Germany with RV "Polarstern" (legs II/2, 1983 and III/2, 1984) and FRV "Walther Herwig" in 1985. - Arch. FischWiss. 37, 1-234.

Anonymous, 1990. Südatlantik-Zirkumpolarstrom. In: Forschungs-Schiff Meteor Reise. Institut für Meereskunde, Leitstelle Meteor, Hamburg, 11, 1-41

Bacescu, M., 1988. Cumacea I. In: Crustaceorum catalogus. Ed. by H.-E. Gruner \& L. B. Holthuis. Kluwer, The Hague, 7, 1-173.

Barnard, J. L. \& Given, R. R., 1960. Morphology and ecology of some sublittoral cumacean Crustacea of southern California. - Pacif. Nat. 2, 153-165.

Fütterer, D. K., 1988. Die Expedition Antarktis VI mit FS "Polarstern" 1987/88. - Ber. Polarforsch. 58, $1-267$

Hempel, G., 1985. Die Expedition Antarktis III mit FS "Polarstern" 1984/85. - Ber. Polarforsch. 25, $1-209$

Jones, N. S., 1971. The fauna of the Ross Sea. Part 8: Cumacea. - N.Z. Dep. sci. Ind. Res. Bull. 206, $33-41$.

Ledoyer, M., 1977. Cumacés (Crustacea) des hles Kerguelen recueillis par le N.O. “La Japonaise" en 1972 et 1974 et par le M.S. "Marion Dufresne" en 1974. - Com. ntn. fr. Rech. antarct. 42, 193-213.

Lomakina, N. B., 1968. Kumovy raki antarktischeskoj oblasti. - Fauna Mor. 6 (14), 97-140.

Stebbing, T. R. R., 1913. Cumacea. - Tierreich 39, 1-210.

Watling, L., 1991. Revision of the cumacean family Leuconidae. - J. crust. Biol. 11, 569-582. 


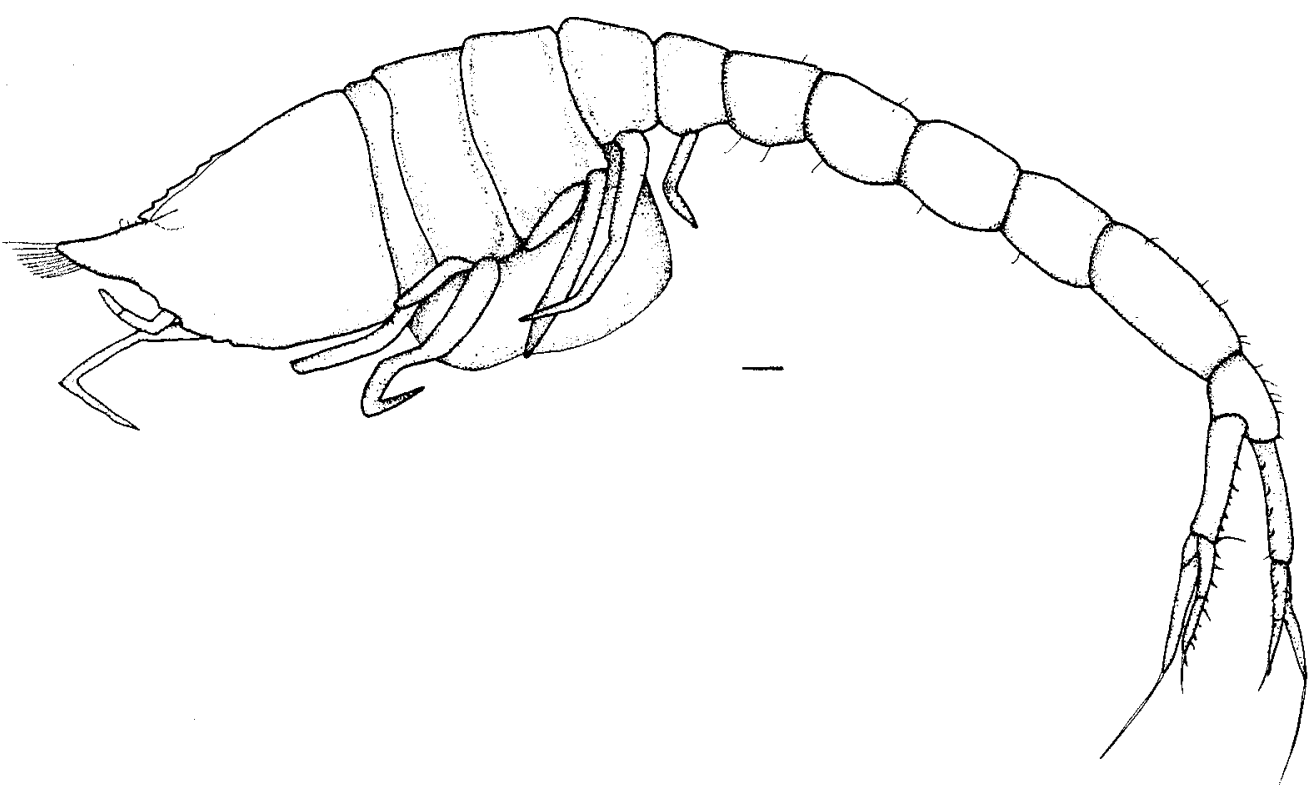

Fig. 1. Leucon intermedius n.sp., female. Habitus; scale bar $0.1 \mathrm{~mm}$

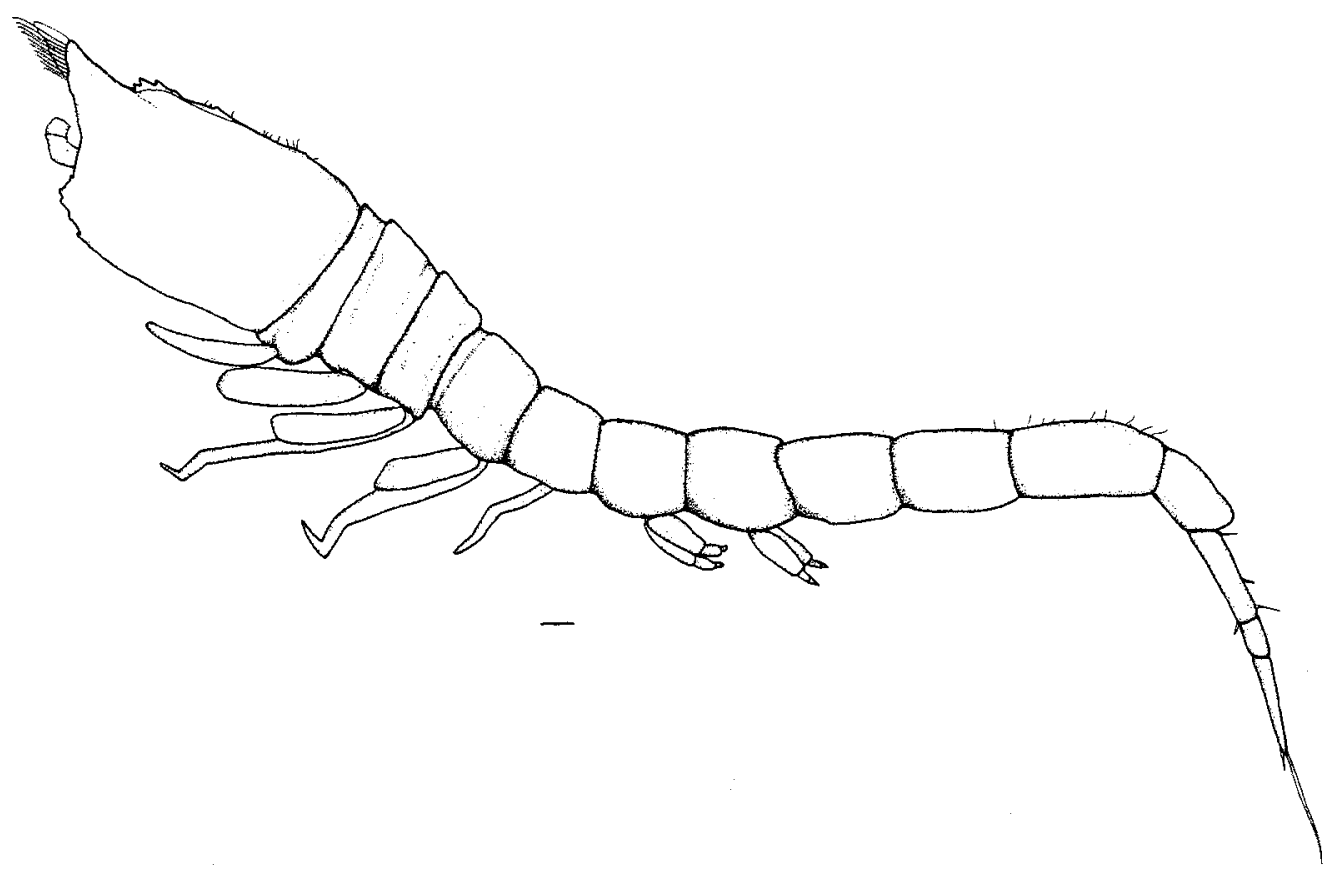

Fig. 2. Leucon intermedius n.sp., male. Habitus; scale bar: $0.1 \mathrm{~mm}$ 


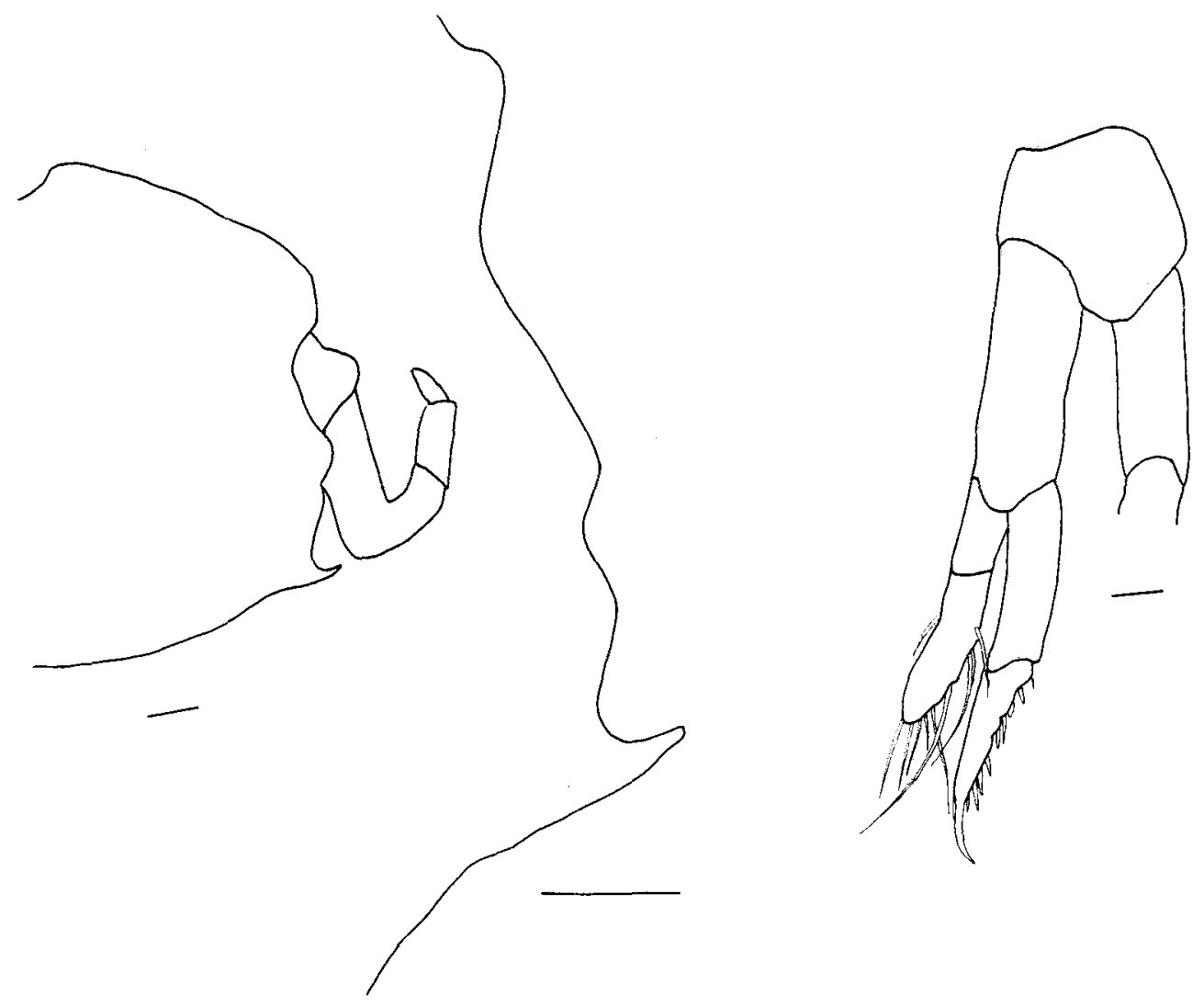

Fig. 3. Eudorella splendida Zimmer 1902, holotype, juv. male. Anterolateral margin (left); uropod (right); scale bars: $0.1 \mathrm{~mm}$ 


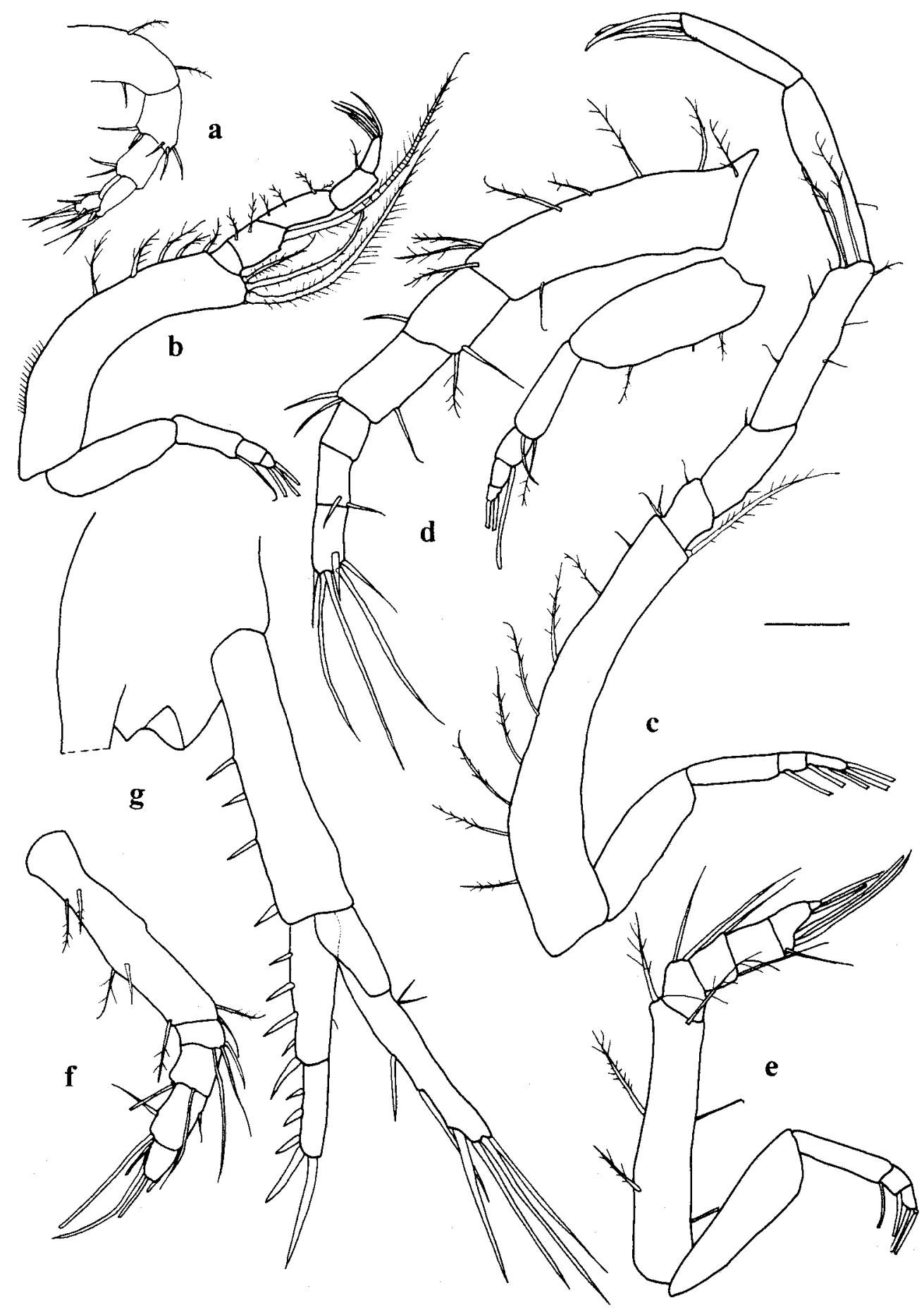

Plate 1. The extremities of Leucon intermedius n.sp., female. Fig. a antenna 1; Fig. b maxilliped 3; Fig. c pereiopod 1; Fig. d pereiopod 2; Fig. e pereiopod 3; Fig. f pereiopod 4; Fig. g telson and left uropod; scale bar: $0.1 \mathrm{~mm}$ 
402

U. Mühlenhardt-Siegei
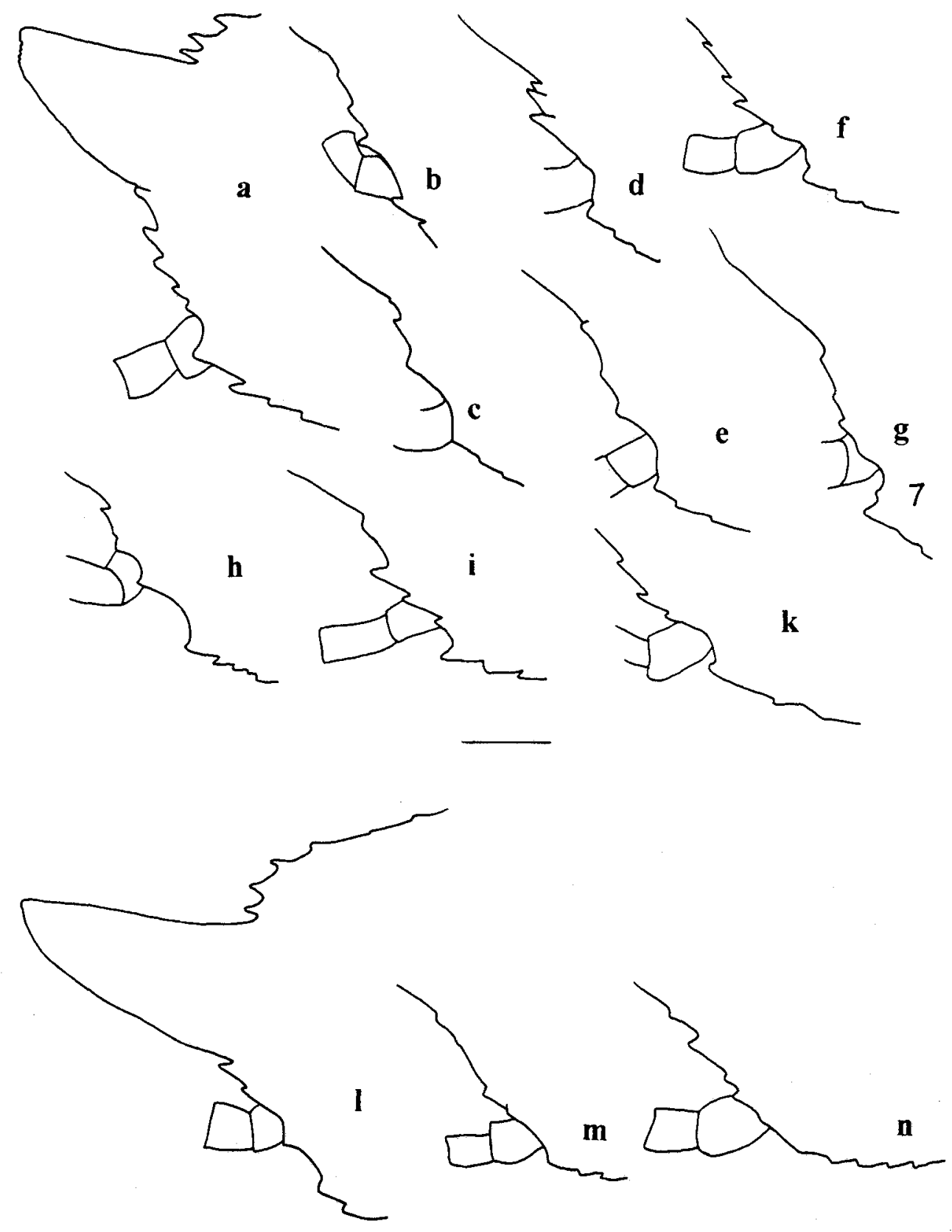

Plate 2. The variability of the anterolateral margin of Leucon intermedius n.sp. Fig. ark female; Fig. b juvenile; Fig. h (paratype) and i: subadult; Fig. e, g and k adult; Fig. ln male; scale bar: $0.1 \mathrm{~mm}$ 


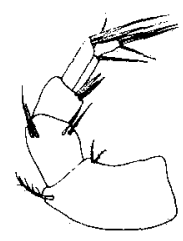

a

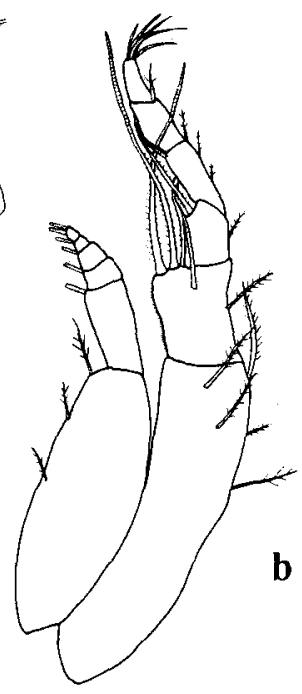

b

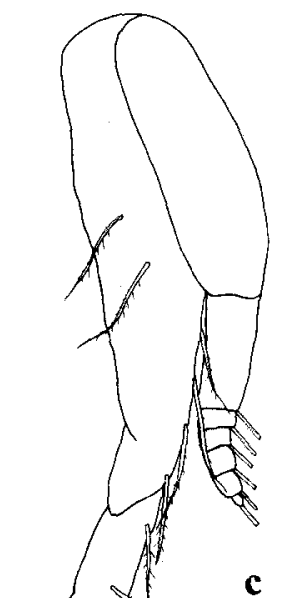

c
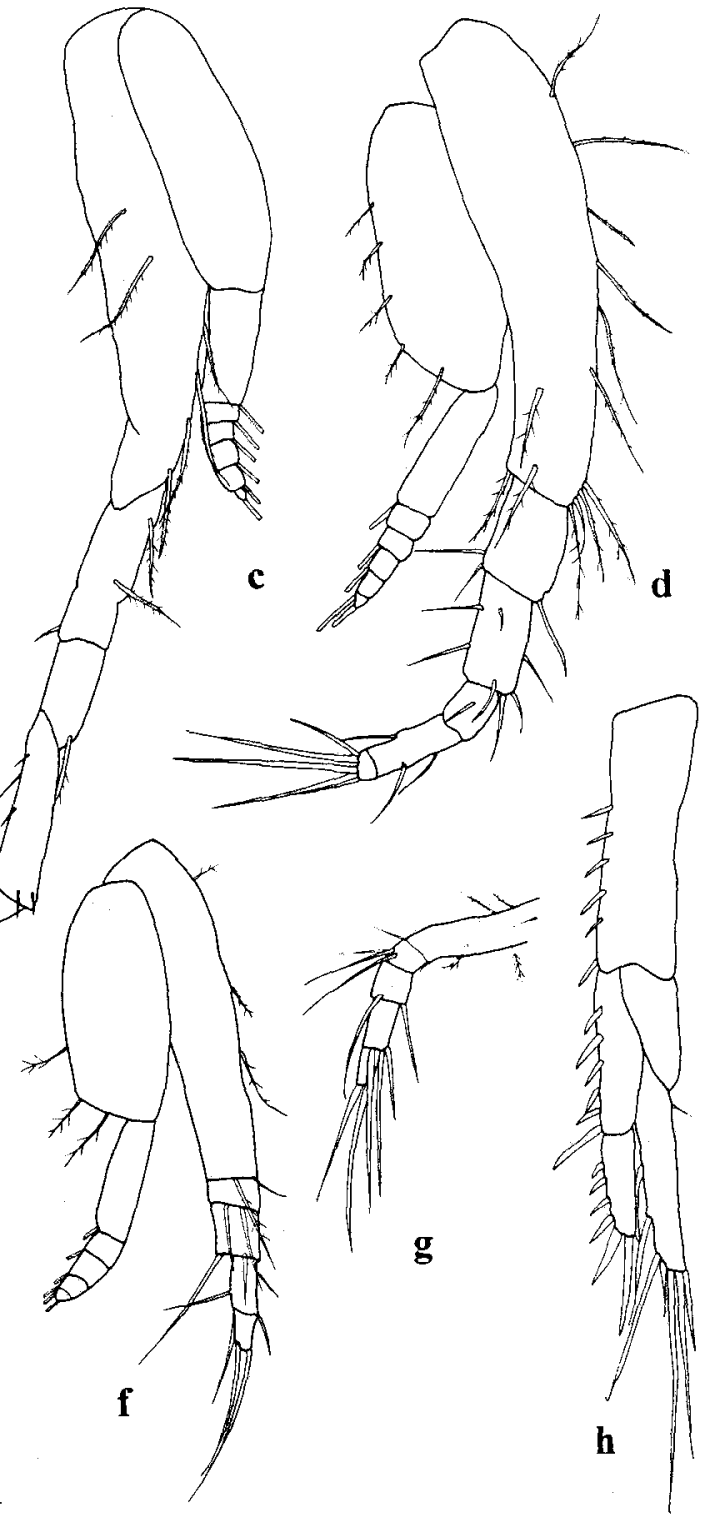

e
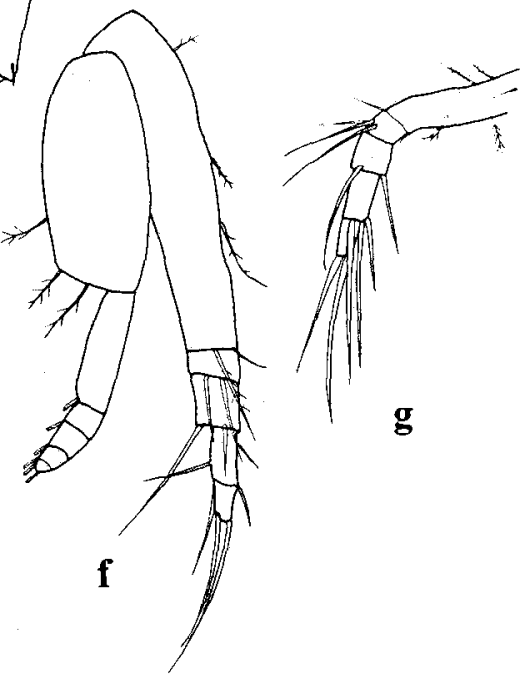

$\mathbf{g}$
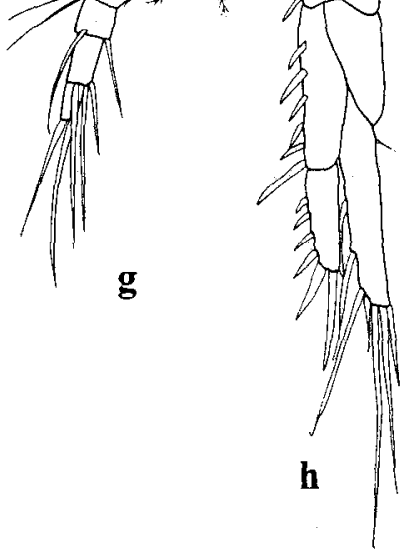

Plate 3. The extremities of Leucon intermedius n.sp., male. Fig. a antenna $1_{i}$ Fig. b maxilliped $3 ;$ Fig. c pereiopod 1; terminal article is missing; Fig. d pereiopod 2; Fig. e pereiopod 3; Fig. f pereiopod 4; Fig. g pereiopod 5; Fig. h right uropod; scale bar: $0.1 \mathrm{~mm}$ 


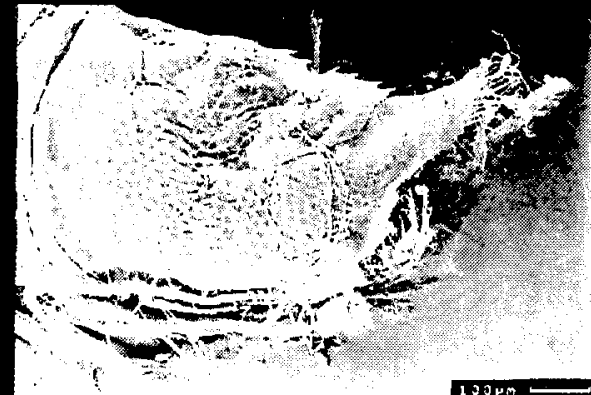

$130 \mathrm{pm}$

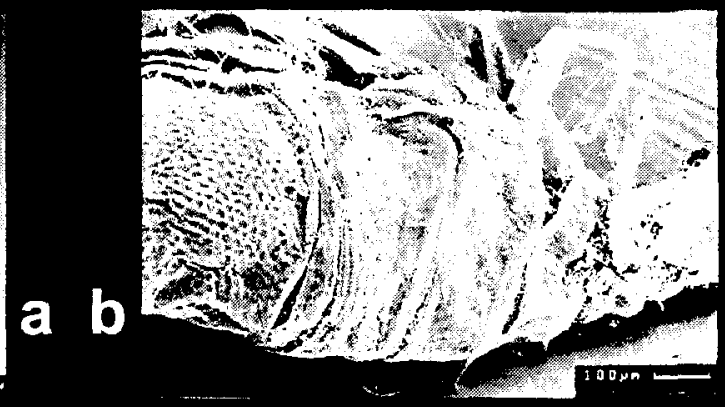

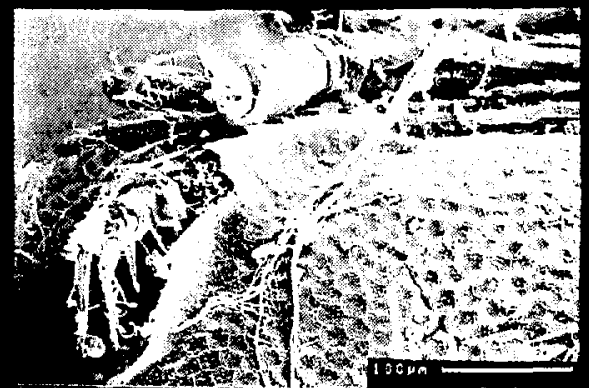

\section{c}
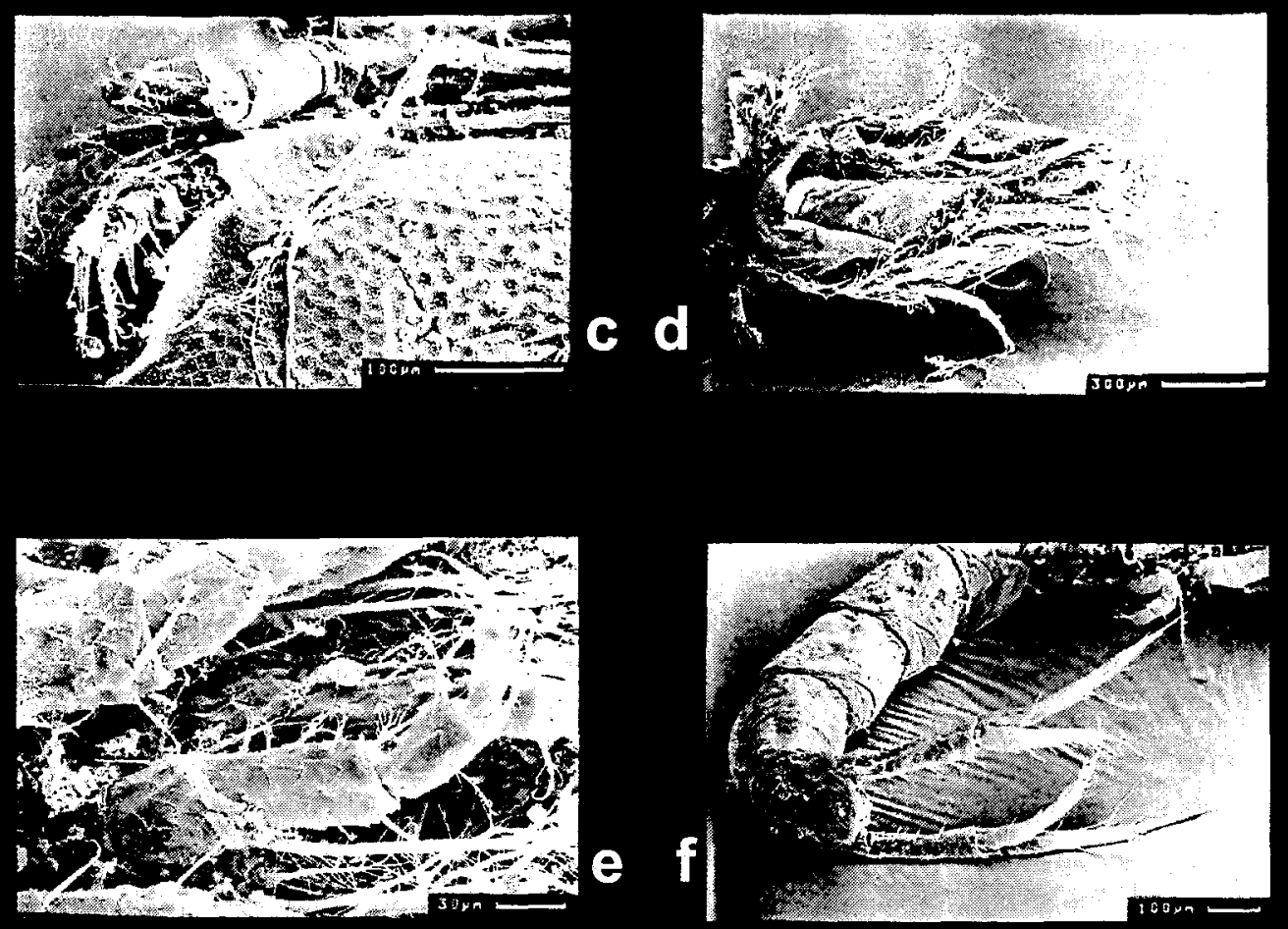

Plate 4. SEM photographs of Leucon intermedius n.sp., adult female. a: carapace; b: free thoracic segments; c: antennal notch $d$ : thorax seen from ventral; e: maxilliped 3; f: telson and uropods 


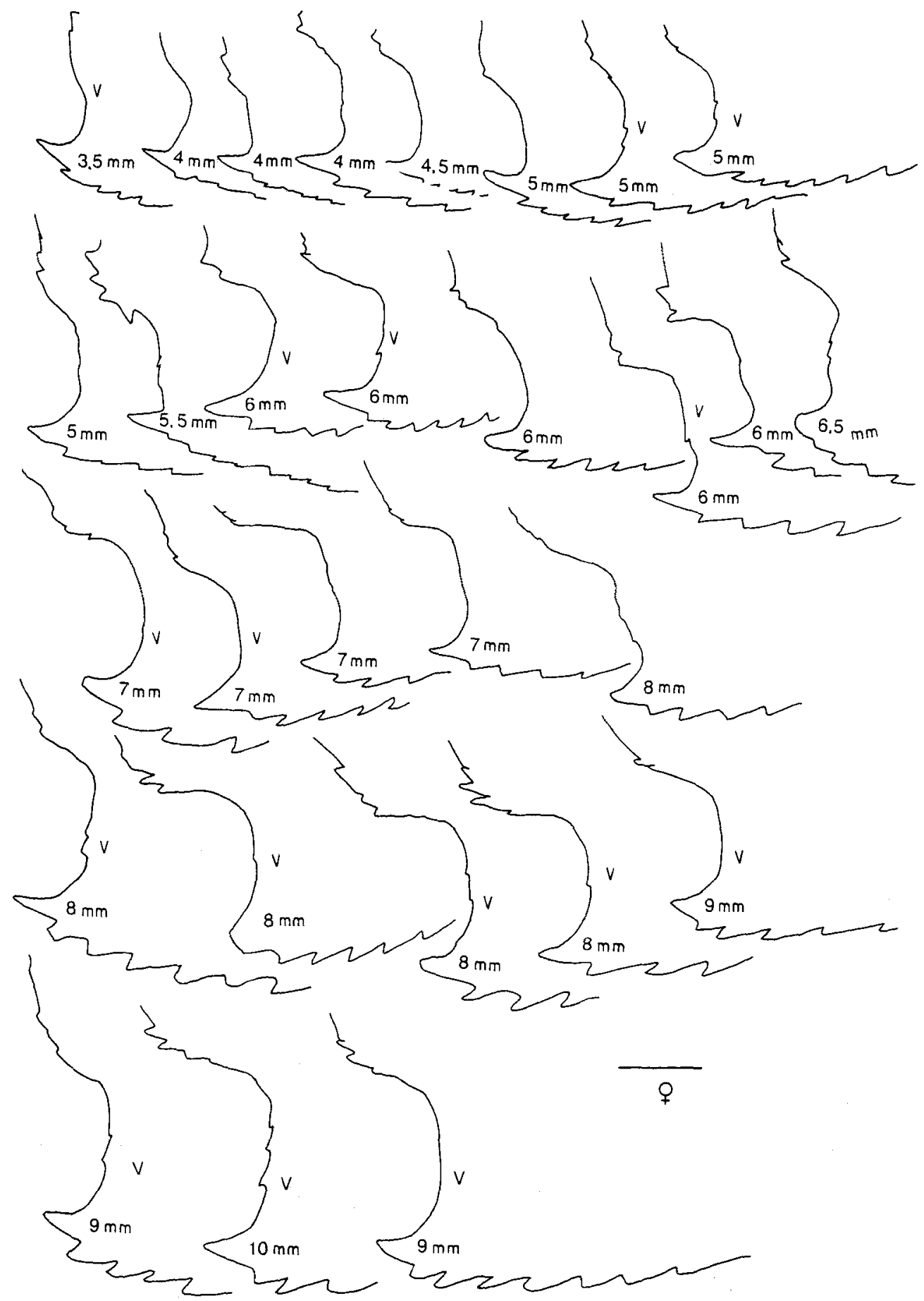

Plate 5. Eudorella gracilior Zimmer 1907, female, anterolateral margin. Scale bar: $0.1 \mathrm{~mm}$; the total length of each specimen is given. The specimens marked with V are from the Victoria Museum material, the others from the Antarctic Peninsula 
406

U. Mühlenhardt-Siegel

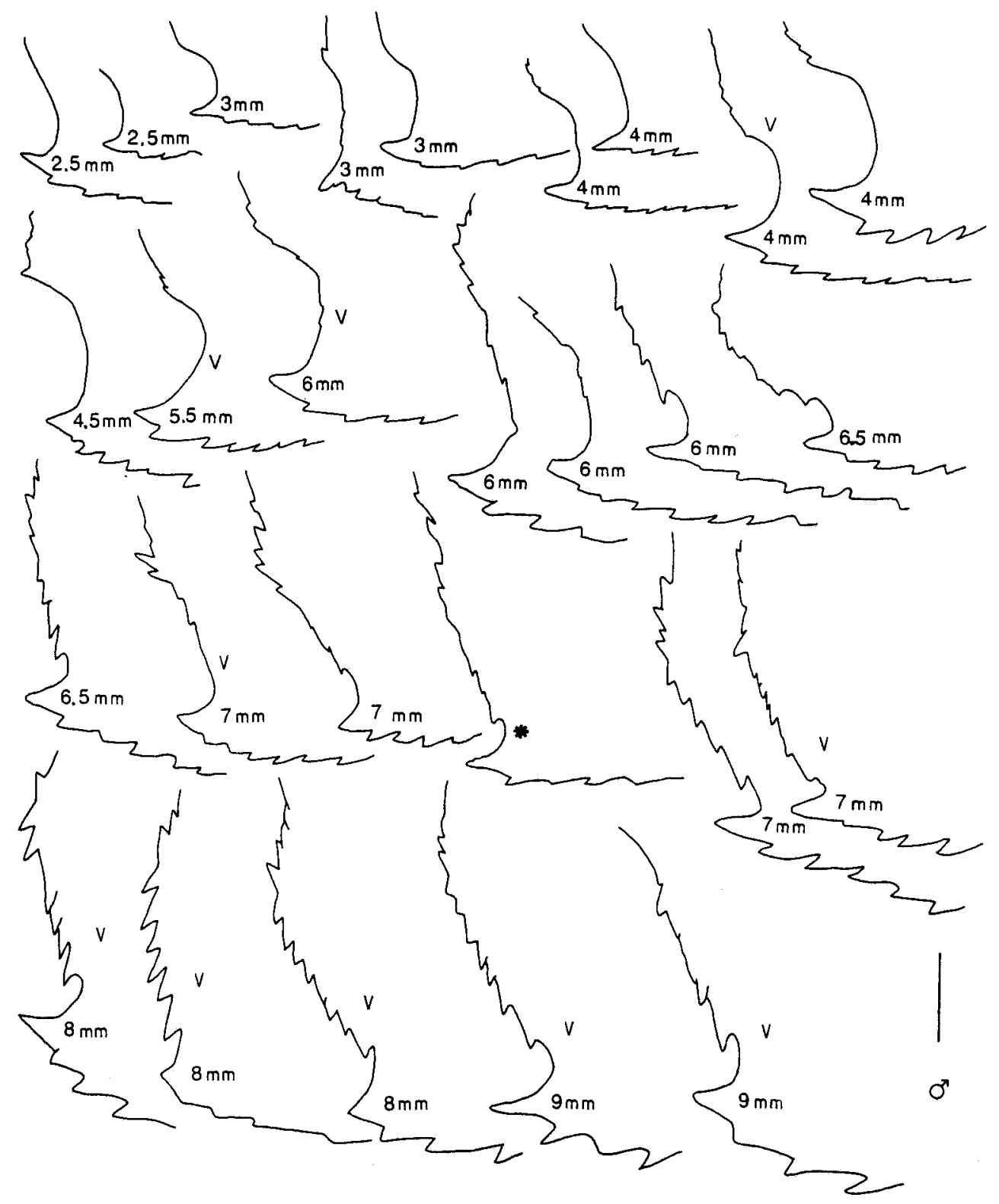

Plate 6. Eudorella gracilior Zimmer 1907, male, anterolateral margin. Scale bar: $0.1 \mathrm{~mm}$; the total length of each specimen is given; * abdomen was missing. The specimens marked with $V$ are from the Victoria Museum material, the others from the Antarctic Peninsula 
Antarctic Leuconidae: Leucon intermedius n. sp.
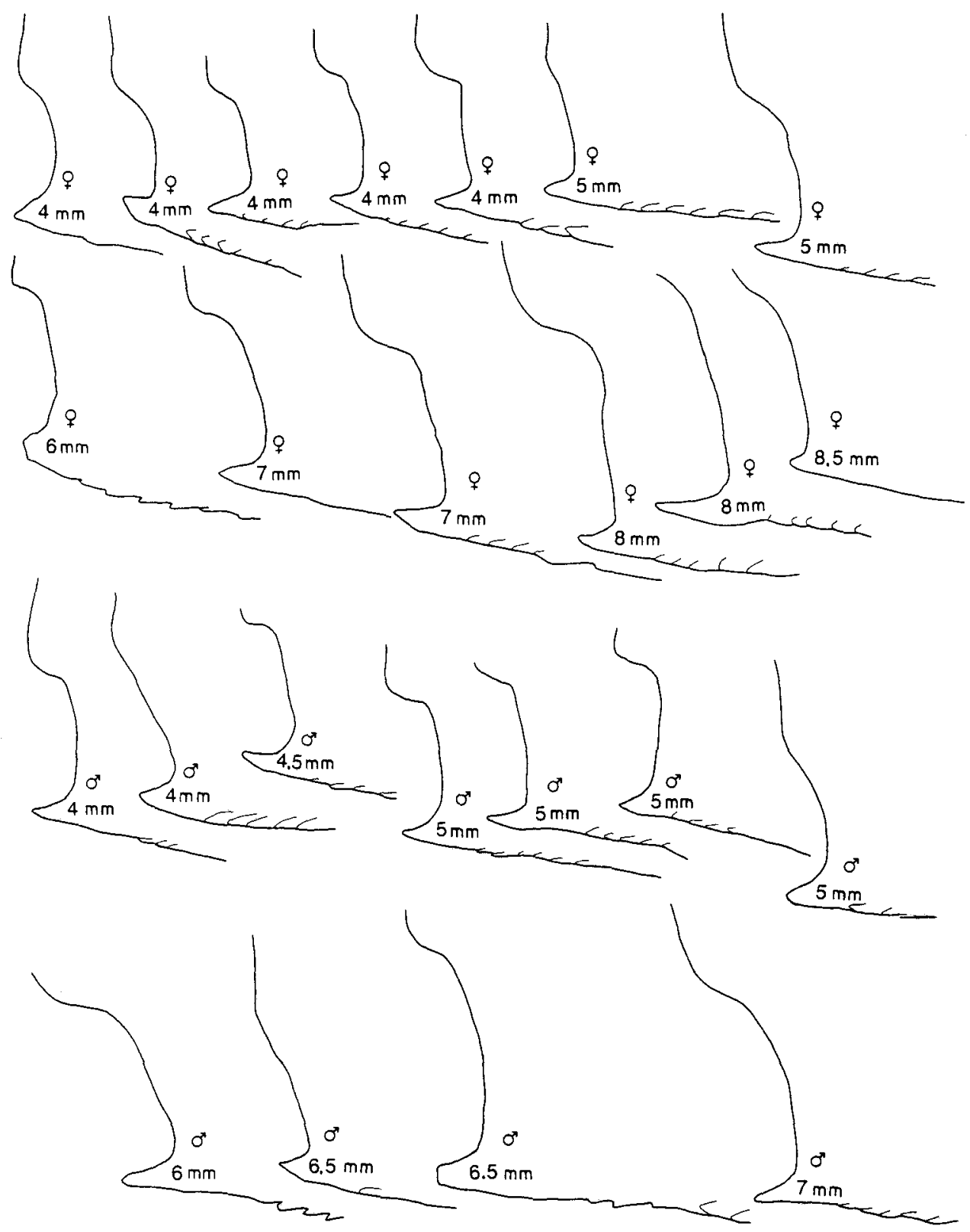

Plate 7. Eudorella cf. fallax Zimmer 1909, anterolateral margin in females and males. Scale bar: 0.1 $\mathrm{mm}$; the total length of each specimen is given 


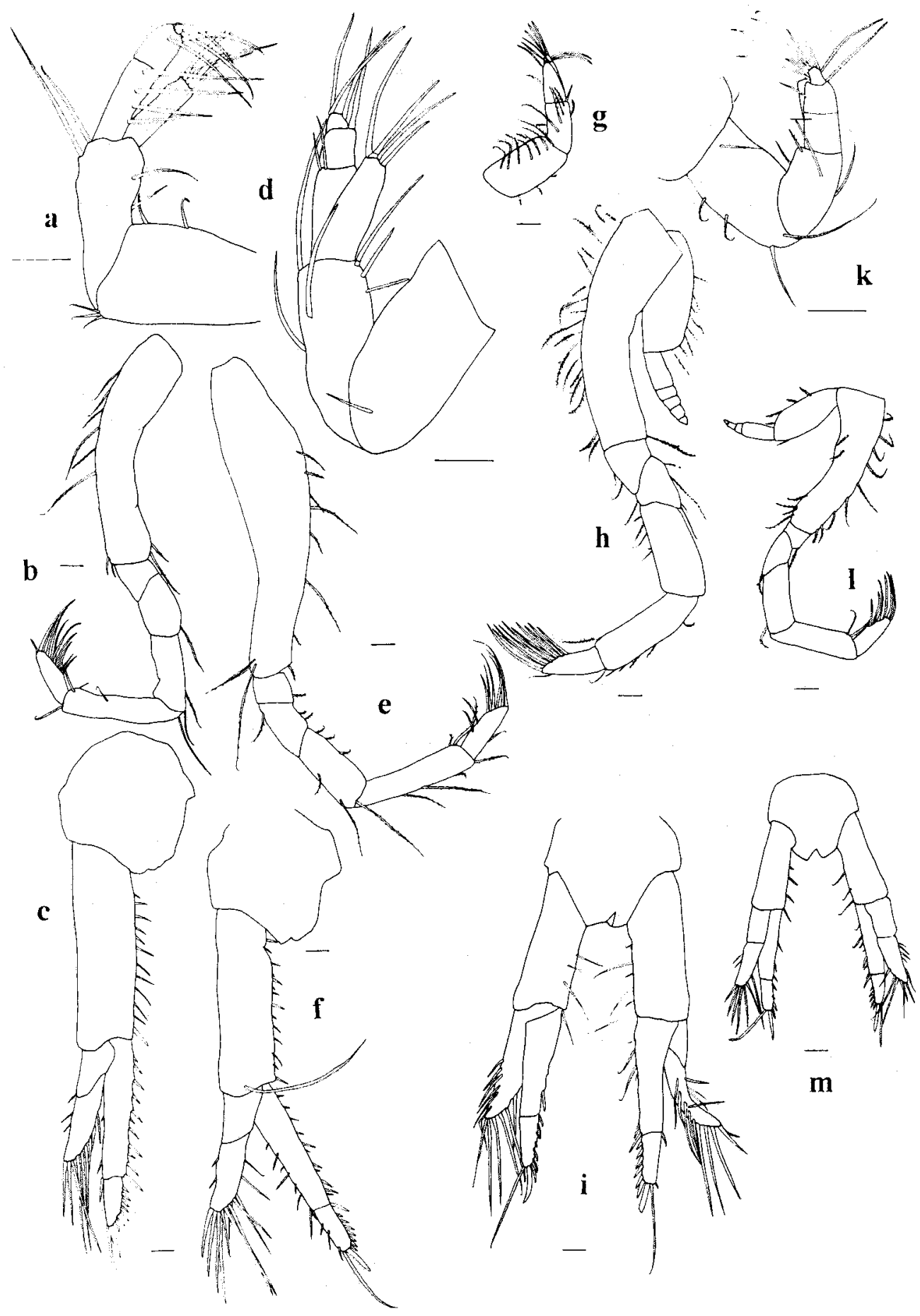

Plate 8. a-c: Eudorella gracilior, female. Fig. a: antenna 1; Fig. b: pereiopod 1; Fig. c: left uropod; d-f: Eudorella gracilior male; Fig. d: antenna 1; Fig. e: pereiopod 1; Fig. f: left uropod; g-i: Eudorella cf. fallax, female; Fig. g: antenna 1; Fig. h: pereiopod 1; Fig. i: uropods; k-m: Eudorella cf. fallax, male; Fig. k: antenna 1; Fig. l: pereiopod 1; Fig. m: uropods; scale bars: $0.1 \mathrm{~mm}$ 